\title{
IAMJ
}

INTERNATIONAL

AYURVEDIC

MEDICAL JOURNAL

Case Report

ISSN: 2320-5091

Impact Factor: 6.719

\section{AGNIKARMA WITH TAMRA SHALAKA IN THE MANAGEMENT OF GRIDHRASI W.S.R TO SCIATICA - A CASE STUDY}

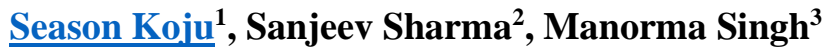

${ }^{1}$ PG scholar, PG Department of Shalyatantra, National Institute of Ayurveda (deemed to be University), Jaipur, Rajasthan, India

${ }^{2}$ Vice- chancellor, National Institute of Ayurveda (deemed to be University), Jaipur, Rajasthan, India

${ }^{3}$ Lecturer, PG Department of Shalyatantra, National Institute of Ayurveda (deemed to be University), Jaipur,

Rajasthan, India

Corresponding Author: kojuseason977@gmail.com

\section{https://doi.org/10.46607/iamj4409072021}

(Published Online: July 2021)

Open Access

(C) International Ayurvedic Medical Journal, India 2021

Article Received: 21/06//2021 - Peer Reviewed: 25/06/2021 - Accepted for Publication: 26/06/2021

Check for updates

\section{ABSTRACT}

Gridhrasi indicates a typical gait that resembles Gridhra/vulture. When vitiated Vata affects the Kandara (ligaments) of Parshni (heel) and Padanguli (toes), it restricts the movement of the lower limb i.e., Sakthi kshepa Nigraha. This condition is called Gridhrasi. Gridhrasi can be correlated to sciatica in modern parlance as there is radiating leg pain along with sciatic nerve distribution in sciatica. The condition has the potential to become chronic and intractable, with major socio-economic implications making the sufferer miser and crippled. As far as modern science is concerned, no promising management is available so far. Many treatment protocols for Gridhrasi have been advised by our Acharyas like Aausadh Chikitsaa, Snehan, Svedan, Sodhan, Agnikarma, Siravyadha which is simple and cost-effective. In this case study, a patient suffering from Gridhrasi was treated with Agnikarma by Tamra Shalaka given three sittings once a week for three weeks. The patient got relief after treatment. From this case study, it can be concluded that Gridhrasi can be treated effectively by Agnikarma and is highly encouraging.

Keywords: Agnikarma, Gridhrasi, Sciatica, Tamra Shalaka. 


\section{INTRODUCTION}

Ayurveda has counted Gridhrasi under Nanatmaja Vatavyadhi. In Gridhrasi, vitiated Vayu induces Stambha (stiffness), Ruk (pain), Tod (pricking sensation) in Sphik (buttock) first and then in Kati (waist), Pristha (hip), Uru (thigh), Jaanu (knee) and Paada (calf and foot) respectively where there is frequent Spandan (twitching) ${ }^{1}$. The main symptom of sciatica is a lumbosacral radicular leg pain that follows a dermatomal pattern radiating below the knee and into the foot and toes ${ }^{2,3}$. The incidence of this ailment is reported 28 per 1000 persons each year in various studies. Similarly, an incidence of 11.6 episodes per 1000 persons each year for the low backache with sciatica is reported $^{4}$. The intervertebral disc herniation causing nerve root impingement is the cause for sciatica in around $90 \%$ of cases ${ }^{5}$. It is more common in the third and fourth decades of life. ${ }^{6}$ Most patients with sciatica are managed conservatively first but results are not satisfactory. Agnikarma is one of the para surgical procedures which can be used to manage Gridhrasi. With the busy lifestyle today, people demand effective treatment in less time where Agnikarma fits perfect.
Moreover, the diseases treated with Agnikarma doesn't have chances of re-occurrence ${ }^{7}$. The therapeutic use of Agni can be called Agnikarma. In this study, an approach for managing Gridhrasi effectively has been carried out through Agnikarma with Tamra Shalaka.

\section{Case History:}

\section{History of present illness}

Demographic details of the patient are shown in the table below. A 55-year-old man visited OPD of Shalyatantra, National Institute of Ayurveda, Jaipur with complaints of pain in the lower back region radiating towards the right lower limb to the posterior aspect of thigh, knee and calf muscles for two months. He had also complaints of stiffness and heaviness in the low back region and right lower limb, tingling sensation and numbness in the right lower limb, difficulty while walking and bending the right knee. He had associated symptoms of constipation. Examination of the patient including vitals, Astavidh Pariksha and specific locomotor system were done and give in the table below.

Table 1: Showing demographic details.

\begin{tabular}{|l|}
\hline OPD registration number \\
\hline Age \\
\hline Sex \\
\hline Address \\
\hline Marital status \\
\hline Occupation \\
\hline Socio-economic status \\
\hline Education \\
\hline Religion \\
\hline Height \\
\hline Weight \\
\hline
\end{tabular}

48443

55 years

Male

Johri Bazar, Jaipur, Rajasthan

Married

Service

Lower middle

Literate

Hindu

$87 \mathrm{~kg}$

5,5 " (1.65100 metres)
History: No history of Trauma. No history of significant systemic illness. No surgical intervention.

Personal history: The patient lives in an urban residence. He is a vegetarian with a good appetite. Sleep is disturbed due to pain. The nature of his occupation is sedentary. No addiction to alcohol or smoking. Family history: There are not any similar complaints to other family members.
Nidaan Panchak: Nidaan: Ruksha and Katu Rasa Aahar and sedentary lifestyle. Aggravating factorsage-related degenerations.

Purvaroopa: vague pain in the low back and discomfort while walking.

Rupa: radiating low back pain, stiffness, numbness heaviness in the low back and right lower limb, disturbed sleep due to pain, changes in gait. 
Upasaya: Rest and sleeping in a supine position causes relief in signs and symptoms.

Samprapti: Due to Vataprakopa Aharvihar, Vata is vitiated and causes Avarodh (obstruction) in Vatavahini Naadi (neural conduction) and provoking radicular pain from Kati, Prustha, Uru and Janu causing Gridhrasi.

Investigations: Routine blood investigations showed $\mathrm{Hb}, \mathrm{TC}, \mathrm{DC}, \mathrm{ESR}, \mathrm{CRP}, \mathrm{RA}$ factors.

Table 2: Showing Physical Examinations

Physical examinations

Body built

Nutritional status

Blood pressure

Pulse rate

Respiratory rate

BMI

\author{
Slight heavy \\ Good \\ $130 / 80 \mathrm{~mm}$ of $\mathrm{Hg}$. On the right arm, sitting position \\ $78 \mathrm{bpm}$, regular, normal \\ $18 / \mathrm{min}$ \\ $31.96 \mathrm{~kg} / \mathrm{m}^{2}$
}

Table 3: Showing Astavidh Pariksha

\begin{tabular}{|l|l|}
\hline Nadi (pulse) & $78 \mathrm{bpm}$ \\
\hline Mala (stool) & Asamyak (no complete evacuation, constipated) \\
\hline Mutra (urine) & Samyak \\
\hline Jeevha (tongue) & Saam (coated) \\
\hline Shabda (speech) & Spashta (clear) \\
\hline Sparsha (skin) & Anushnasheeta \\
\hline Drik (eyes) & Prakrit \\
\hline Akriti (posture) & Madhyam \\
\hline
\end{tabular}

Table 4: Showing Systemic examinations

\begin{tabular}{|l|l|}
\hline Nervous system & Grossly intact \\
\hline Respiratory system & Bilateral NVBS, No added sound \\
\hline Cardiovascular system & $\mathrm{S}_{1} \mathrm{~S}_{2} \mathrm{M}_{0}$ \\
\hline Gastrointestinal system & Non tender, no organomegaly \\
\hline Urogenital system & No abnormality defined \\
\hline
\end{tabular}

Table 5: Showing Examinations of the specific locomotor system.

\begin{tabular}{|l|l|}
\hline Inspection & Limping gait, Difficulty in walking, no swellings or deformity seen \\
\hline Palpation & Tenderness 2+ at L5S1 region, Local temperature is normal., Muscle tone- good \\
\hline Special test & SLRT (active)- right leg-45 ${ }^{0}$ Left leg- $90^{\circ}$, Braggards test- positive for right leg at $40^{\circ}$ \\
\hline
\end{tabular}

Treatment Given: The patient was given intervention with Agnikarma by Tamra shalaka in the low back region (L4-L5 region). Poorvakarma: The patient was positioned in a prone position on the table. The most tender spots over the low back were marked followed by draping with a sterile cut sheet. Pradhankarma:
Samyak Twak dagdha was done by red hot Tamra Shalaka in rosette pattern i.e., one Bindu (dot) in central surrounded by six Bindus in the periphery in the marked points. Paschatkarma: Ghrikumari pulp was rubbed over the Dagdha Vrana. Gauze impregnated with Yasthimadhu Churna was applied over the Vrana. 

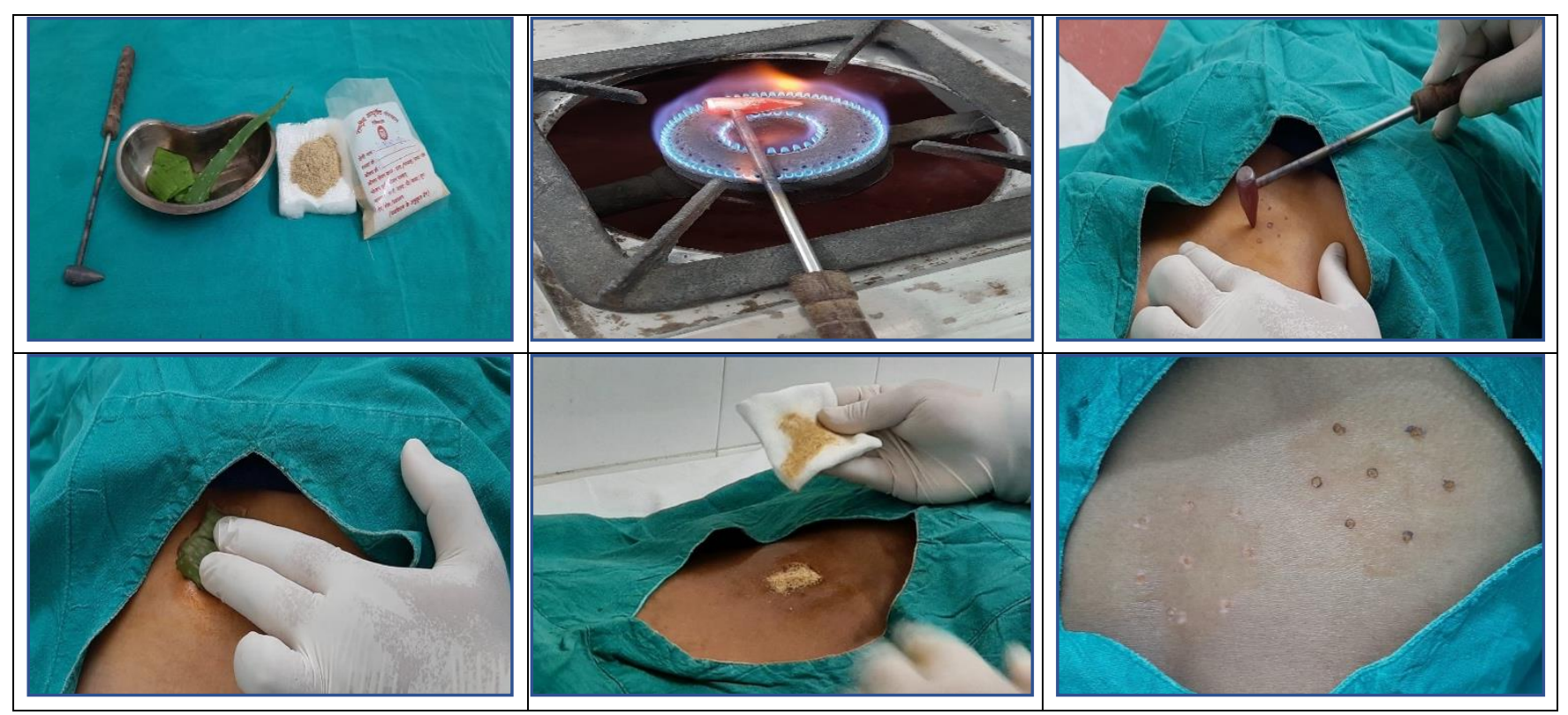

No oral medications were given. Three sittings of $A g$ nikarma were done once a week for three weeks. The points for Agnikarma differed from the previous one. The patient was assessed after each sitting the very next day. After completion of three sittings, the patient was called on follow up for a month once in two weeks.

\section{Observations and Result}

The patient got better in every sitting. He found significant relief in lumbar pain, tingling sensation and heaviness. Gait was improved. Assessments were carried out by specific subjective and objective criteria on $0,2^{\text {nd }}$ day, $8^{\text {th }}$ day, $15^{\text {th }}$ day and $30^{\text {th }}$ day shown in the table.

Table 6: Assessment findings

\begin{tabular}{|r|l|l|l|l|l|l|}
\hline S. N & Parameters & Before treatment & $2^{\text {nd }}$ day & $8^{\text {th }}$ day & $15^{\text {th }}$ day & $30^{\text {th }}$ day \\
\hline 1. & Stambha (Stiffness) & $3+$ & $2+$ & $2+$ & $1+$ & $1+$ \\
\hline 2. & Ruja (Pain) & $6+($ VAS $)$ & $4+$ & $3+$ & $1+$ & $1+$ \\
\hline 3. & Radiation of pain & $2+$ & $2+$ & $1+$ & 0 & 0 \\
\hline 4. & Tingling sensation & $2+$ & $1+$ & $1+$ & 0 & $1+$ \\
\hline 5. & Toda (Pricking sensation) & $2+$ & $1+$ & 0 & 0 & 0 \\
\hline 6. & Spandan (Twitching) & $1+$ & $1+$ & 0 & 0 & 0 \\
\hline 7. & Aruchi (Anorexia) & 0 & 0 & 0 & 0 & 0 \\
\hline 8. & Tandra (Drowsiness) & 0 & 0 & 0 & 0 & 0 \\
\hline 9. & Tenderness & $3+$ & $2+$ & $1+$ & 0 & $1+$ \\
\hline 10. & SLRT (Right leg) & $45^{0}$ & $60^{0}$ & $80^{0}$ & $90^{0}$ & $90^{0}$ \\
\hline 11. & Braggart's test (Right leg) & Positive & positive & Positive & Negative & Negative \\
\hline
\end{tabular}

\section{DISCUSSION}

Agnikarma has potential effective results in the management of Gridhrasi. It can be used for symptomatic treatment of Gridhrasi. Because of Usna, Tiksna, Suksma, Asukari Guna of Agni, being opposite to vitiated Vatika Guna and Vitiated Kapha Guna,
Agnikarma clears the Srotavarodh pacifying Prakupit Vata and Kapha maintaining Samavastha Agnikarma upsurges Rasarakta Samvahan so that pain-producing substances are flushed away. The transferred Agni causes Utkleshana of Dhatvagni, which act against vitiated Ama Dosha in Dushya by Dosha Pachana. 
Thus, Sama and Nirama Dosha gets Neutralise. This causes Samprapti Vighatana, and the patient's signs and symptoms are corrected. Here in this case study, Tamra shalaka was used as it has good conduction of heat, easy to attend red hot, handy and easily achieved Samyak Twak Dagdha. From in modern perspective, Blood flow to the skin is regulated through two branches of the sympathetic nervous system i.e., the noradrenergic vasoconstrictor system and the Cholinergic vasodilator system. These two mechanisms or systems affect the thermoregulation of the surface of the body. Heating diminishes nerve sensitivity and increases blood flow to the tissue. It also increases tissue metabolism, relaxation and flexibility of muscles. Heat activates thermoreceptors over the skin that are in connection with its blood vessels. It releases bradykinin that is responsible for vasodilation as it relaxes smooth muscles wall. The muscle relaxation occurs due to a decrease in the flow of alpha motor neurons and gamma efferent. The regulation of heat in the body is mediated by calcium channels that cause an increment in intracellular calcium. Increase intracellular calcium generates action potentials which stimulates sensory nerves and makes the brain feel the heat. These channels belong to TRPV (Transient receptor potential vanilloid)) receptors. TRPV1 and TRPV2 get sensitize when there is noxious heat and TRPV4 to normal physiological heat. Activation of these channels causes inhibition of purine pain receptors i.e., $\mathrm{P} 2 \mathrm{X} 2$ and $\mathrm{P} 2 \mathrm{Y} 2$ receptors that lie in the endings of peripheral nerves. For example, heat causes direct inhibition of peripheral pain. But for deeper pain, heat activates peripheral pain receptors that cause alteration in the gate control of the spinal cord thus reducing deeper pain.

\section{CONCLUSION}

The patient has a recurrence in symptoms like tenderness and tingling sensation. This may be because of Vata provoking Aahar-Vihar of the patient. This study is about the presentation of the single case only. In today's world with a busy lifestyle, people demand effective treatment in less time where Agnikarma can be the best treatment option. It is a safe, acceptable and cost-effective Ayurveda treatment modality that needs furthermore researches for establishing it as a first option treatment protocol for musculoskeletal disorders. This interventional procedure can be combined with other treatment modalities to get a synergistic effect.

\section{REFERENCES}

1. Agnivesh. Charaka Samhita elaborated by Charaka and Dridhbala with the Ayurvedadipika commentary by Shree Chakrapanidatta edited by Vaidya Yadavji Trikamji Acharya, Varanasi: Chowkambha Surbharati Prakashan; Edition 2017. Chikitsasthana-28/56 Page no. 619.

2. Valat JP, Genevay S, Marty M, Koes B. Sciatica. Best Pract Res Clin Rheumatol.2010; 24:241-252.

3. Harrison's principle of internal medicines, Anthony S, Fauci editors, Mc Graw hill publications, $15^{\text {th }}$ edition, vol. 2001

4. Frymoyer JW. Lumbar disc diseases: Epidemiology. Instr Course Lect. 1992; 41: 217-23

5. B.W koes, M Wrantulder, Diagnosis and treatment of sciatica, BMJ.2007:334: 1313-1317.

6. Stanley, J. swierzewski, Remedy Health media: sciatica overview www.healthcommunities.com.

7. Sushruta. Sushruta Samhita, with Nibandhasangraha commentary of Dalhanacharya \& Nyayachandrika of Sri Gayadasacharya on Nidanasthana edited by Vaidya Yadavji Trikamji Acharya\& the rest by Narayan Ram Acharya 'Kavyatirtha', Varanasi: Chowkambha Surbharati Prakashan. Edition 2018. Sootrasthana 12/3.

\section{Source of Support: Nil Conflict of Interest: None Declared}

How to cite this URL: Season Koju et al: Agnikarma With Tamra Shalaka In The Management Of Gridhrasi W.S.R To Sciatica - A Case Study. International Ayurvedic Medical Journal \{online\} 2021 \{cited July 2021\} Available from: http://www.iamj.in/posts/images/upload/1588_1592.pdf 